\title{
Poverty in Indonesia
}

\author{
Yuliani $^{1^{*}}$
}

\author{
${ }^{1}$ Postgraduate, Universitas Negeri Makassar, Indonesia \\ *Corresponding author.Email:yuli020873@gmail.com
}

\begin{abstract}
This type of qualitative research uses a phenomenological approach, while the results show that the poverty rate continues to increase every month and every year, this indicates that the problem of poverty is a very important problem to find a solution, the impact of poverty has an impact on all social, political, economic, and social fields. education and all other sectors, and this condition is able to weaken the passion and work ethic of the community, there needs to be synergy and cooperation from all national components, stakeholders, government, private sector, education sector and society in managing and improving community conditions in various fields.
\end{abstract}

Keywords: poverty, society, policy, behavior, hunger

\section{INTRODUCTION}

Indonesia's population is one of the largest populations in southeast Asia, where population growth increases year after year, with a large population if managed optimally will certainly provide benefits for the state, but the reality is actually bad, such as high poverty rates, low health quality, and unemployment problems spread in each region, these problems are difficult to overcome, So that serious efforts are needed to overcome the problem, and this must involve various sectors that must cooperate with each other.

Poverty is like a vicious cycle, which is interlocking related, the biggest difficulties experienced in handling poverty are due to the mindset of the community and not optimal handling of poverty, the model of poverty in Indonesia has a different character, so the handler must be solved micro- because poverty in the village is different from in the city, while the poverty of each city is different so it is very difficult to cope with one policy model.

\subsection{Problem Formulation}

a. What is the current state of poverty in Indonesia?

b. What is the current policy in Indonesia to alleviate poverty?

\subsection{Purpose}

a. To find out the current state of poverty in Indonesia

b. To know the current policies in Indonesia to alleviate poverty

\section{LITERATURE REVIEW}

Poverty is a condition in which a person is unable to meet basic needs which include primary and secondary aspects. The primary aspect is poor knowledge and skill assets, while the secondary aspect is poor social networks, financial resources, and informal, such as lack of nutrition, water, housing, poor health care and relatively low education [1].

The World Bank has issued a ratio for measuring a person's poverty level, which is based on the minimum standard of spending ability of each person in a household to meet their daily needs. In other words, a person is included in the poverty criteria if his expenditure or income does not reach Rp. 13,000 per day.

It is undeniable that the government has played a major role in this decline. However, this role is not in terms of job creation, means of improving the quality of human resources, or increasing welfare. Instead, they continuously poured funds, either directly or indirectly. For example, through subsidies for food, electricity, fuel, and other social assistance, the percentage of which continues to increase. Even now, people who are slightly above the poverty line are still in danger of decreasing their welfare. The slightest economic misfortune can make them down grade to become poor citizens.

Meanwhile, according to the Central Statistics Agency [2] in order for a person to live a decent life, the fulfillment of food needs alone will not be enough, 
therefore it also needs to be met with basic non-food needs, such as housing, education, health, clothing, and various other goods and services. In summary, the poverty line consists of two components, namely the food poverty line and not food.

\subsection{Characteristics of Poor Households}

Based on the high birth rate that occurs in a country will not cause poverty in the country itself but with a high birth rate will be an advantage in the field of development of a country if it is able to be used as well as possible in order to reduce unemployment and have a good impact on improving the economy of a country [3].

\subsection{Educational Characteristics of Poor Heads of Households}

Poverty and education have an interrelated relationship, due to poverty experienced by a person, the person will not be able to study in formal schools or study in high education, so that the condition causes knowledge and understanding related to trying to find a decent job experiencing obstacles, in general people who have an education have a tendency to work decently, but the obstacle is the ability of companies in providing salaries. felt less, while other needs are increasing [4].

In poverty, income is an important measure to categorize a person can be declared poor or not. If someone works and has an income then they are categorized as the head of the family. After income, the second factor is a person's dependents in his family. As the head of the family, they must have dependents such as wives, children, grandchildren, and other family members. Therefore income and dependents will play an important role in categorizing someone as poor or not.

\subsection{Concept of Poverty}

There are three types of concepts of poverty: absolute poverty, relative poverty, and subjective poverty. Absolute poverty is formulated by making a certain measure concrete (a fixed yardstick). Each country has a different absolute poverty limit because the basic living needs of the people used as a reference are different. Because the size is ascertained, this concept of poverty knows the poverty line.

The concept of relative poverty is formulated based on "the idea of relative standards" by paying attention to the dimensions of place and time. The basis of the assumption is that poverty in one region is different from other regions, and poverty at one time is different from another time. This concept of poverty is usually measured based on the consideration (in terms of judgement) of community members, especially with a degree of survival. This concept was also criticized, especially because it was very difficult and constantly fickle. It is worthy of a particular community that it is not worthy of another community, and so it is also feasible at the present time it may not be for the future [5].

Subjective poverty is formulated based on the poor itself. This concept does not recognize a fixed yardstick, does not take into account the idea of relatives standard. A group that, by our measure, falls below the poverty line, may consider itself poor or vice versa. And the group that in our feelings is classified as living in an unworthy condition, may not think so. Therefore, this concept is considered more appropriate when used to understand the right and formulate effective ways or strategies for its countermeasures.

\subsection{Dimension of Poverty}

Poverty can be classified into two categories: cultural perspective and structural or situational perspective. Cultural perspectives approach the problem of poverty at three levels of analysis, namely individuals, families, and society.

Poverty is a thing experienced by the community which is characterized by those who behave extravagantly, prioritize their wants over their needs and this has an impact on their income so that they are unable to manage their finances by considering their income and expenses. So it can be said that poverty is characterized by the nature of someone who behaves extravagantly.

The poor at the city level have not been handled in an integrated and sustainable manner, only temporary assistance programs, should be planned, measured and sustainable so that a little efforts to deal with poverty can be overcome gradually and the tone of results in the community. Implementation of the program [6].

Sociologically, the structural dimensions of poverty can be traced through the "institutional arrangements" that live and develop in our society. The basic assumption is that poverty is not solely rooted in "self-weakness", but also because it is not optimal from the program made by the government, even if there is a poverty alleviation program more to provide consumption assistance without building its human character to be independent and creative in finding economic resources [6]. 


\section{METHOD}

Types of qualitative research through
phenomenological approaches

\section{RESULT AND DISCUSSION}

\subsection{Poverty in Indonesia}

The percentage of poor people in urban areas as of March 2018 was 7.02 percent, down from 7.26 percent in September 2017. Similarly, in rural areas, where the percentage in March 2018 was 13.20 percent, down from September 2017's position of 13.47 percent. Suhariyanto revealed that a number of factors that affect the poverty rate from September 2017 to March 2018 are general inflation in that period of 1.92 percent and average monthly per capita spending for households in the bottom 40 percent which grew 3.06 percent, When considering all dimensions of adequate consumption welfare, reduced vulnerability, education, health and access to basic infrastructure, nearly half of Indonesians can be considered to have experienced at least one type of poverty [5].

In recent years, Indonesia has made some progress in the field of human development. There has been a real improvement in the achievement of education at the elementary school level, improvements in basic health care coverage (especially in terms of maternity and immunization assistance), and a very large decrease in child mortality. However, for some indicators related to the MDG (millennium development goals), Indonesia failed to achieve meaningful progress and lagged behind other countries in the same region. The impact of poverty causes

a. Low nutritional quality: because most people who have low incomes, so can not afford quality food so that many people are often sick, and not passionate in work and easily tired.

b. Low quality of education: in general, people have both formal and non-formal education, but the quality aspect has not been able to do this due to low passion for learning, unable to buy the latest book books, and many teacher educators who have not optimal knowledge.

c. High crime rate: due to the insistence on the necessities of life, many people do things crime due to the increased need for life while work is difficult to come by.

d. Unemployment: the difficulty of finding a job makes many people unemployed

\subsection{Poverty Inequality between Regions}

The existence of different regional conditions certainly have economic, social, cultural conditions also experience differences, so that in handling poverty is also not the same, there are residents whose lives are always moving, so that the conditions are suited to be monitored by the government, while there are others whose lives are settled and tend to live for a long period of time, the presence of immigrants who seek income in large cities tends to make many lives in the city, usually they are seasonal 2 weeks settled in the city then they return to the area of origin then soon they come again, The poverty rate in Java / Bali is 15.7 percent, while in Papua is 38.7 percent. Basic services are also uneven between regions, due to the lack of facilities in remote areas. In Java the average household distance to the nearest health center is four kilometers, while in Papua 32 kilometers. Meanwhile, 66 percent of the poorest fifths of the group in Java/Bali have access to clean water, while kalimantan only 35 percent and for Papua only 9 percent [6].

\subsection{National Community Empowerment Program (PNPM Mandiri)}

This program is a superior program owned by the government, this is because the community as an empowered object and subject is greatly helped in terms of business capital assistance and development, although until now the empowerment program has not been optimally run, the concept of community empowerment has the meaning that the community must get out of poverty by doing productive activities that can produce measured through the benefits that can be, The ability to survive various economic crises makes people have to find business opportunities, and must be able to face various challenges both from inside and outside.

The handling of poverty cannot stand alone, but must involve society as an object and subject of development, meaning that society must have the spirit to get out of poverty through productive, creative and always accompanied by learning and continuing to learn to achieve a better life, to support these efforts, the approach that will be taken is as follows [7]:
a. Strengthening at the subdistrict and village level
b. Build synergy between government and society
c. Cooperate
d. Strengthening local resources
e. Cultural approach

\subsection{Activity Component}

PNPM in its implementation is carried by several main activity components [3], including:

a) Community Development:

Activities to build critical awareness of the community through poverty reflection, mapping 
problems, potentials and needs, participatory planning, community organizing, resource utilization, monitoring, to the maintenance of development results.

b) Direct Community Assistance:

Stimulant funds as a means to implement activities that have been planned by the community. Especially for the villages left behind is allocated Rp250 million /village.

c) Increase government capacity:

Assistance for local governments in facilitating community activities.

d) Program Management and Development Assistance:

Activities to support the government and various other caring groups in the management of program activities, quality control, study and evaluation activities, as well as for the improvement and development of programs.

\subsection{Government efforts in overcoming poverty in Indonesia:}

The government's efforts in overcoming poverty in Indonesia [8], are as follows:

a. First Step Economic assistance to the community The government conducts macroeconomic strategies and policies including the provision of business capital assistance aimed at people who have businesses, but in reality the assistance is widely used for example business capital assistance used for consumption needs.

b. At the macroeconomic level, the government encourages inclusive economic growth, maintains macroeconomic stability, stabilizes prices, creates productive jobs, maintains the investment climate, maintains trade regulation, increases the productivity of the agricultural sector, and develops infrastructure of disadvantaged regions. "For microeconomics, for the very poor and poor, the government seeks to provide food assistance (rastra) and Non-Tunal Food Assistance (BPNT), Conditional Cash Assistance (Family Hope Program), and Health Insurance Contribution Assistance Of Healthy Indonesia Card. Furthermore, for the poor and vulnerable, the government seeks to increase income with access to capital, improve product quality and marketing access, develop business service skills, and develop entrepreneurship, partnerships, and aerospace.

c. The second step: minimizing poverty through the development of community-based productive activities, where the element of empowerment plays an important role, the community is invited to do productive activities, in addition, help in the form of capital and development is also done by the government, in addition the government must cooperate with the private sector in this case is a business actor of the scale of the upwards to jointly encourage economic progress based on regional potential.

d. The third step is to reform the subsidy budget. Allocations for fuel subsidies have fallen significantly since 2015 . The allocation of subsidies is transferred to the Village Fund and Regional Transfer to reduce inequality. Subsidy reforms continue to ensure target accuracy, fiscal sustainability and energy diversification.

e. The fourth step is to increase the social protection budget. In the period 2010 to 2018, a significant reduction in subsidies, from 3.4 percent to 0.8 percent of GDP in the period 2015 and 2018 was allocated to social protection through health insurance premiums for the poor as well as the expansion of social assistance programs. In 2018, a sizable budget will be allocated to infrastructure and economic investment.

f. The fifth step is the strategy of implementing economic independence and management in terms of importing a number of goods from outside, so that the calcification of goods and economic transactions in a region can run.

g. The problem of poverty is not an easy problem to solve but if not taken seriously this country will be a failed country in the eyes of the world besides that surely the level of criminality will increase because people do not have jobs that can provide income for their families. in the long run poverty will be very detrimental to the reputation of this country that has failed to prosper all its people and its great influence. with the gerasi successor of our nation in the future because of poverty so that they do not get enough nutrition and difficulty costs to study in school. As a result, poverty can be predicted that in the future we will be fooled by countries that are hungry for our produce, poverty becomes a very complex problem for developing countries including in Indonesia, for many academics make programs and strategies to deal with poverty, but the concept is sometimes not followed up by the government, while the authority to handle poverty is on the government side. Synergy is needed in overcoming poverty.

\section{CONCLUSION}

Poverty is a condition in which a person is unable to fulfill basic needs which include primary and secondary aspects, namely knowledge and skills. Various poverty 
alleviation efforts have been carried out for a long time, but their implementation has not been optimal and tends to be unsustainable, the many problems in Indonesia are the biggest obstacles in efforts to reduce poverty, so seriousness and seriousness and integrative efforts to overcome poverty are needed.

It is undeniable that the government has played a major role in this decline. However, this role is not in terms of job creation, means of improving the quality of human resources, or increasing welfare. Instead, they continuously poured funds, either directly or indirectly. For example, through subsidies for food, electricity, fuel, and other social assistance, the percentage of which continues to increase. Even now, people who are slightly above the poverty line are still in danger of decreasing their welfare. The slightest economic misfortune can make them down grade to become poor citizens.

\section{ACKNOWLEDGMENTS}

We would like to express our deepest gratitude to the Chancellor of the Makassar State University, the Director of the Postgraduate Program, and friends who have provided support for the implementation of this research.

\section{REFERENCES}

[1] Sumardi, Mujianto et al. Poverty and Basic Needs. Jakarta: Rajawali Press.

[2] Arulpragasam, Jehan and Vivi Alatas. 2007. New Era in Poverty Alleviation in Indonesia, The World Bank: Jakarta.

[3] Sherraden, Michael. Assets for the Poor. Jakarta: Rajawali Press, 2005.

[4] Irianto, Sumarjo Gatot. "PUAP Companion Technical Instructions 2015" http://www.pertanian.go.id/assets/upload/doc/ Juknis Companion PUAP 2015.pdf

[5] Pangestika, Cindhera Rian. "Implementation of Rural Agribusiness Business Development Program (PUAP) (Gapoktan Tri Abadi Case Study ngompro village pangkur district of Ngawi)", Journal of Public Administration, Vol.3,No.5, hal. 752-757

[6] Tambunan, Tulus.T.H., 2011. Indonesian economy, Jakarta: Ghalia Indonesia.

[7] Regulation of the Minister of Agriculture of the Republic of Indonesia Number 06/Permentan/OT.140/2/2015 on Guidelines for The Development of Rural Agribusiness Business in Fiscal Year 2015.
[8] Cakrawijaya, Muhammad Amin and Bambang Riyanto. "Evaluation of Rural Infrastructure Development Program in Wonokerto Village, Turi Subdistrict, Sleman Regency", Journal of Regional and Urban Planning, August 2014,25(2), p.137-156.

[9] Sherraden, Michael. Assets for the Poor. Jakarta: Rajawali Press, 2005.

[10] Fakih, Mansour. Civil Society for Social Transformation. Yogyakarta: Pustaka Pelajar, 2004.

[11] Soetomo. Social Problems and Their Solution Efforts. Yogyakarta: Pustaka Pelajar, 2008. 